\title{
English-Tigrinya Intrasentential Code-switching on Tigrinya FM Radio Programs (TFRPs)
}

\author{
Bahire Araya Keleta \\ Woldiya University College of Social Sciences and Humanities; Department Of English Language and Literature
}

\begin{abstract}
This study deals with the linguistic analysis of Tigrinya-English(Tiglish) code-switching phenomenon: the case FM Radio Programs broadcasting in and around Mekelle. The rationales, which triggered the researcher to conduct such a research, are the fact that there are very few studies in Ethiopia, no research in Tigray, and the researcher was experienced with switched Tigrinya in the Tigrinya FM radio programs (TFRPs). The study aims mainly at exploring features of intrasentential code-switching on Tigrinya FM radio services (TFRSs). To address the problems and achieve the objectives, qualitative methods were employed for gathering bits of information from the selected site FM radio listeners in focus. Audio recording was used as basic tools to collect genuine information, and the bits of information were collected from bilingual TFRPs clients and the newscasters. There are bulks of code-switching occurrences on TFRPs more frequently from English and Amharic constituents; Tigrean code-switchers were engaging in code-switching incidences motivated by the sociocultural attractions.
\end{abstract}

Key words: code-switching, intrasentential and Tigrinya FM Radio Program

DOI: $10.7176 / \mathrm{JLLL} / 67-02$

Publication date: April $30^{\text {th }} 2020$

\section{Introduction}

The Ethiosemitic language varieties are divided as southern-Ethiosemitic which includes Amharic, Guraage, Harare, Gafat, and the northern Ethiosemitic in compasses Tigre, Tigrinya and Geez. They are spoken in the northern east of the horn of Africa except the last one which is limited as liturgical language to the Ethiopian Orthodox Church. Similarly, Tigrinya is spoken in the north parts of Ethiopia Tigray region, and in Eritrea (cf. Hetzron 1972).

Moreover, the start of the print media opened the way for the start of (digital) audio, video, and audio-video media transmissions in Tigray. The first radio services in Tigrinya language were started at the end of 1958 in Asmera. Birhane $(1995,614)$ points out that this radio station was the property and voice of the then Ethiopian governments until the down fall of the Derg in 1991. Dimitsi weyane Tigray (radio Tigray) was started in 1969 in collaboration with radio Eritrea and stood by itself after two years in 1971. This radio has had full-fledged services on its course of long historical period till now. Following the government decree allowing nongovernmental organizations free air in the country, FM radio Finot (latter FM 104.4) was started at the end of 2007 , and other private owned FM radios were started following this opportunity in Ethiopia as a whole and in Tigray as well . Presently, there are about four radio stations in Tigray including the Ethiopia radio Tigrinya program. Two (FM.102.2 aired from Dimtsi weyane and FM 104.4) of them are serving only in areas found within 100 square $\mathrm{km}$ to all directions from the metropolis (Mekelle). The managers of these radio stations' explained that there are Kebeles which are found within this frequency cover and yet do not clearly receive this transmission due to geographical barriers. The only radio which is heard in every corner of Tigray is Dimitsi Weyane in addition to the Ethiopia radio broadcast from Addis-Ababa. Recently, FM radio which is aired from the radio Fana has started to be heard on the frequency of FM 94.8. Nevertheless, the research sites of this study lies on FM 102.2 and 104.4 which are being listened in Mekelle and its surroundings.

It is quite clear that media are one of the best instruments in which language enhancements, socioeconomical, socio-political and socio-cultural issues can be appropriated among other issues. To this end, the language which is used as a medium of transmissions and instructions should be clear and to the point, otherwise, many things may remain on the air without hitting the target points. However, contrary to this reality, many educated bilinguals and few illiterate bilinguals are heard switching or mixing languages or dialects into their matrix language (Tigrinya) while interviewed, and carried out conversation speeches. ${ }^{1}$

\section{Methodology}

To undertake an assessment on intrasentential code-switching on Tigrinya FM radio, audio recordings were used duly.

\footnotetext{
${ }^{1}$ Mengstu (2008) notes that Tigrinya mass Medias are not using 'pure' Tigrinya: there appears lack of selection of words, use of informal speeches, redundancy of ideas and languages, mixing of others language into the assumed standard Tigrinya, in correct use of adjectives and fragment of ideas. In general, bilingual speakers committed grammatical error of the language in addition to mixing or switching inter/intradialectal and other languages (286) (My own translation). ${ }^{1}$
} 


\subsection{Audio Recording}

Recording can be carried out through the bilateral agreement of the researchers and interviewees or without the free will of the respondents. However, the latter has been found unacceptable for some reasons. For example, Widdowson $(1998,10)$ argues as:

Clandestine recording has been tried and largely abandoned. There are practical reasons, for the tapes are usually noisy and require very expensive processing. There are also ethical ones.

Therefore, hidden recordings were not used in this study since they will have many consequences on the finding of the research. The open and overt audio recordings were the main tools that were used to collect information. Tape recordings are now in the open and researchers are generally satisfied that any initial anxiety affecting the level of formality will disappear as an interview continues (Ibid). Audio recordings were used to gather linguistic data from the aired Tigrinya FM radio programs from both FM 102.2 and 104.4.

\subsection{Subject of the Study}

The subjects of this study were Tigrinya FM radio journalists and bilinguals Tigreans who participated in Tigrinya FM radio programs which are aired in and around Mekelle. The aired programs were part of the study to collect linguistic data of code-switching on the Tigrinya FM radios. Both the bilingual journalists and bilingual Tigrinya FM radio participant were BA degree holders and above.

The journalists were given questionnaires through their representatives, of course, with a serious follow up of the researcher. Most of them are permanent workers and a few are contract workers in both FM 102.2 and FM 104.4 stations.

By the same token, the linguistic data were recorded from the daily aired programs of the two stations (FM 102.2and 104.4).

\subsection{Sampling Techniques}

In this study, qualitative way of sampling techniques was used. The qualitative sampling was used to gather linguistic data from the live discussion of daily aired TFRPs. In the two stations (FM 102.2 and 104.4), there are various chunks of daily programs. Thus, the researcher recorded some relevant data from both stations for about a series of four (4) solid weeks. The recorded speeches were loaded in seven (7) cassettes which were later translated into English and then transcribed into the IPA writing systems.

The linguistic data is collected from the live discussion of the FM Tigrinya media. Thus, to collect these lists of information, scientific steps were used as follows. To gather information form live discussions, the following steps were taken into account.

$>$ First, schedule of the daily programs were collected from the FM radio media managers, then the researcher arranged his time budget vis-à-vis this daily radio FM programs.

$>$ Second, suitable programs for the topic to be researched were carefully selected.

$>$ Finally, the speeches from the daily Tigrinya radio programs were tape recorded.

\subsection{Data Analysis}

The analysis is all about linguistic aspects of code-switching. They were analyzed based on the linguistic constraints or models and transcribed qualitatively using the International Phonetic Alphabet (IPA) as an analyzing tool. By the same token, they are glossed vis-à-vis Leipzig glossing rules.

\section{Discussion}

In the Tigrinya FM radios, embedded language items are switched into Tigrinya in phrase and word level (smallsized linguistic constituents). Romaine $(1995,123)$ elaborates intrasententially types of code-switching as: Intra-sentential switching refers to the switching that occurs inside the same clause or sentence which then contains elements of both languages. This type of switching appears to involve special principles governing how the syntax and morphology of both languages may interact and is consequently adopted only by bilinguals with high levels of fluency.

As can be seen from the data given blow, small-sized linguistic constituents are commonly switched into the Tigrinya spoken on the TFRPs. It should be noted that in the sample data it is customary to find multiple English constituents which are mixed intrasententially into Tigrinya in the speech conversations carried out in the TFRPs. Thus, English nouns take the lion share of switching incidence from the sample data, and the mixing or switching of nouns from English into Tigrinya on the Tigrinya FM radio programs was carried out intrasententially but with multiple constituents. Some examples are presented below.

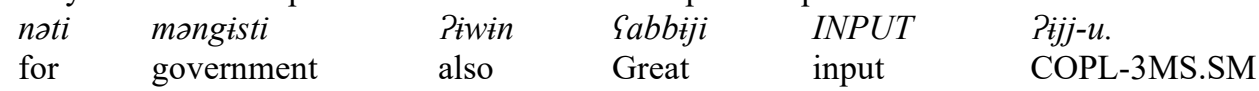

'It is also great input for the government' 


\begin{tabular}{|c|c|c|c|c|c|}
\hline $\begin{array}{l}\text { dims'i wajjana } \\
\text { dimsiweyane }\end{array}$ & $\begin{array}{l}\text { Pab } \\
\text { in }\end{array}$ & $\begin{array}{l}\text { lim } \text { development } \\
\text { develop }\end{array}$ & $\begin{array}{l}\text { CONTRIBUTION-u } \\
\text { contribution-3MS.POSS }\end{array}$ & $\begin{array}{l}\text { liful } \\
\text { high }\end{array}$ & $\begin{array}{l}n \text { najr-u. } \\
\text { COPL.PAST- } \\
\text { 3MS.SM }\end{array}$ \\
\hline
\end{tabular}

'The contribution of dimtsi wejane in development was high.'

3MS.SM

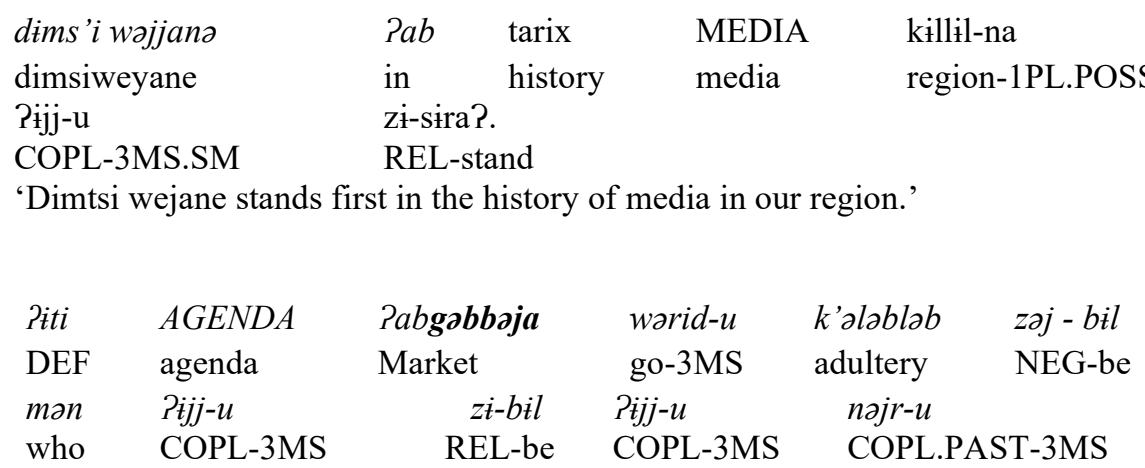

'The agenda was to know the person, who doesn't make adultery in the Market.'

There is constituents form English at noun level which were utilized in intrasententially in the TFRPs in Tigray. This indicates that Tiglish bilingual speakers switched small-sized syntactic constituents overwhelmingly than large-sized constituents. In the above sentences, (1-4) English nouns are inserted into Tigrinya in the Tigrinya conversations on the TFRPs replacing Tigrinya lexemes such as gbi?at, Pastawas'?o, and mąixanat zena respectively.

However, in the following examples, the English words magnet and tourism are inserted into the language and lexicalized as parts of it by borrowing for these words have not any equivalent words in Tigrinya.

$\begin{array}{lr}\text { dək'k'i-Panəsti-jo } & n a j \\ \text { female-3FPL } & \text { for } \\ \text { 'Females are magnet for danger.' }\end{array}$

hadega

MAGNET

Pijj-ən .

'Females are magnet for danger.'

$$
\begin{array}{lll}
\text { zitafalalaj- } u & \text { TOURISM- at } & \text { Palla -wu } . \\
\text { different-3MPL } & \text { tourism- PL } & \text { Exist-3MPL.SM }
\end{array}
$$

'There exist different tourisms.'

In Sentences (4) above, it involves intrasentential code-switching taking one constituent from English and the other from Amharic substituting the Tigrinya words. For example, the nouns in sentence (4) agenda and gabbəja can be replaced with equivalent words in Tigrinya zaSiba and Sidaga respectively.

As can be seen from the above data, noun phrases are highly switched from English to Tigrinya on the Tigrinya FM radio broadcasting programs. There are many English noun phrases in the sample data. Noun phrases are switched intrasententially into Tigrinya taking the second rank next to nouns. It is believed that it may be irksome to put them down all here, so some examples are presented below.

$$
\begin{array}{llll}
\text { dims'i wajjana } & n a j & k^{\prime} \dot{d} d m i t & \text { STACK HOLDER-na } \\
\text { dimsiweyane } & \text { POSS } & \text { First } & \text { stackholder-1PL.POSS }
\end{array}
$$

'Dimtsi wejjane is our first stack holder.'

$$
\text { COPL-3MS.SM }
$$

$$
\begin{array}{lll}
\text { zi-tawasana } & n a j & \text { FIRST AID } \\
\text { REL- some } & \text { POSS } & \text { first aid }
\end{array}
$$

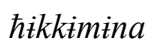
treatments

wasid $-u$. 'He took some first aid treatments.'

\section{[}

$$
\begin{aligned}
& \text { another temperature regulation } \\
& \text { 'There exists another thing which is called Temperature regulation.' }
\end{aligned}
$$$$
\text { take.PFV-3MS.SM }
$$

All the sentences shown above, indicates that English constituents are mixed at noun phrase level intrasententially. As can be understood from this sample data the switched noun phrases are grammatically wellformed and governed to the grammatical rule of the matrix language (Tigrinya). For example, in sentences (7) the English noun phrases are attached to the Tigrinya first person plural possessive morpheme /-na/. Here, almost all the words have not their equivalent words to replace them in the matrix language (Tigrinya). Therefore, 
Trilingual Trigrams are mixed these phrases to fill the lexical gap in Tigrinya.

Above all, adjectives are the third largest constituents which are switched highly into the matrix language (Tigrinya) on the FM radio broadcastings. Consider the following examples.

$\begin{array}{lll}\text { Piti Pakal INFECTIOUS } & j i-\chi \text { - } & \text { INin. } \\ \text { the } & \text { organ infectious } & \text { 3MS.SM-IMP.become }\end{array}$

'The organ will become infectious.'

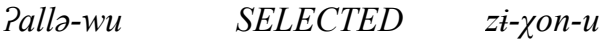

$$
\begin{aligned}
& \text { exist-3MPL selected REL-be - 3MPL }
\end{aligned}
$$

\section{FRUSTRATED ti- \\ frustrated 2MS.SM-IMP.become}

'You will become frustrated.'

The sentences mentioned above show the intrasententially switching of English linguistic constituents into Tigrinya at word level (i.e. adjectives). Adjectives are small-sized constituents of sentences category of any language. Thus, the sample data shows that small-sized linguistic categories (adjectives) are not attached into the bound morphemes of the matrix language like nouns and noun phrases rather they are functioning as post or premodifiers of the nouns in the matrix language by governing to syntactic rules of the language (Tigrinya).

Besides, English verbs are switched intrasententially. They switched either with in a sentence, or clause and phrase forms, but they are not as pervasive as nouns, noun phrases and adjectives. Some examples are listed below.
$\begin{array}{lll}k a b & \hbar a d \partial & P i j j-u \\ \text { form } & \text { one } & \text { COPL-3MS.SM }\end{array}$
MOBLIZE
kojn-u.
'It mobilizes form one.'
mobilize
be-3MS.SM

$\begin{array}{lll}\text { Pizi DECLARE } & k \dot{t}-n \dot{i}-g a b r-o & \text { Pi-na. } \\ \text { this declare } & \text { FUT-1PL-do-3MS.OM } & \text { COPL-1PL.SM } \\ \text { 'We will declare this, } & \end{array}$

$\begin{array}{llll}\text { Pabzi } & \text { mos'i?-u } & \text { DEVELOP } & \text { kojn-u. } \\ \text { here } & \text { come-3MS } & \text { develop } & \text { be-3MS.SM } \\ \text { 'It }\end{array}$

'It comes and develops here.'

As in the above examples, English verbs are switched into Tigrinya intrasententially, and the switched verbs take Tigrinya morphemes to keep the grammaticality of the matrix language.

Besides, adverbs are among the highly switched linguistic constituents into the matrix language on the FM radio broadcastings in and around Mekelle from English intrasententially. Let us see the following instances.
bizuh-at Pijj-om
many - PL COPL-3MPL.SM
ACTUALLY.
'They are many actually.'

$\begin{array}{lll}\text { gize-na } & \text { EFFECTIVELY } & \text { Paj-ni-t'ik'k'ommi-n . } \\ \text { time-1PL.POSS } & \text { effectively } & \text { NEG -1PL.SM-IMP.use-NEG }\end{array}$

'We do not use our time effectively.'

The above data reveal that English adverbs that are switched intrasententially into Tigrinya speech conversations on the FM radio. Bilingual Tigreans are switching an adverb to modify Tigrinya verbs in the Tigrinya dominated morpho-syntactic situations on their speeches. However, this code-switching phenomenon is carried out superfluously either replacing the Tigrinya equivalent adverbs or denying the adverb marker /bi-/.

Moreover, the sample data portray that there are an intrasententially switching of both coordinating and subordinating conjunctions from the embedded language (English) into the matrix language (Tigrinya). Examples are listed below.

$\begin{array}{ll}\text { hadə } & \text { Pa } \chi^{\prime} \chi^{\prime} \text { iha } \\ \text { one } & \text { material }\end{array}$
OR GENERATOR
Pì-n-bill-o REL-1PL-call-3MS

$\begin{array}{lllllll}\text { EVEN } & \text { IN } & \text { DORMM } & \text { Pab } & \text { UNIVERSITY } & \text { jit- } \hbar \text { aftr } & \text { nəjr-ə. } \\ \text { even } & \text { in } & \text { dorm } & \text { In } & \text { university } & \text { 3PS.SM-IMP.shy } & \text { COPL-1PS.SM }\end{array}$

'I was shy even in dorm in university.'

The English subordinating and coordinating conjunctions are presented on sentences numbers (18and19) 
which were switched into the conversational speeches of Tigrinya on the FM radios intrasententially. From this reality, one can understand that English subordinating and coordinating conjunctions are employed intrasententially overwhelmingly. In this case Pfaff $(1979,294)$ proposes that until very recently, intrasentential code-switching was considered syntactically random rather than rule governed behavior.

Coordinating conjunctions are used to connect two equal grammatical valued clauses whereas subordinating conjunctions are used to join two or more unequal grammatical valued clauses. Thus, there is not any possibility that subordinate and coordinate conjunctions to occur together functioning the same thing.

Besides, verb phrases are among the less or non-switchable linguistic constituents of the embedded languages intrasententially such as pronouns, negative markers, affirmative markers and independent clauses. Tigrinya and English have different grammatical surface structures; the head of the verb phrase in Tigrinya is the same as its sister Amharic language. The inflecting verb coding person, number gender, and tense; a transitive verb also takes an object marker plus an object complement preceding the verbal head. Thus, the non-occurrence of English verb phrases on the Tigrinya speeches are due to this grammatical dissimilarity between English and Tigrinya. Macswan $(2000,46)$ as cited in Gass (n.d) confirms that code-switching at PF generates "unpronounceable" elements because phonological system cannot be mixed. Therefore, this reason is the case for the point in English and Tigrinya code-switching at the level of verb phrase.

The negative and affirmative markers can appear in Tigrinya speech conversational turn. There was only one negative and one affirmative markers were recorded from English cognates which are presented as follows.

\begin{tabular}{|c|c|c|c|c|c|c|}
\hline $\begin{array}{l}\text { no no } \\
\text { nono }\end{array}$ & $\begin{array}{l}\text { Piti } \\
\text { the }\end{array}$ & $\begin{array}{l}\text { ћakim } \\
\text { nurse }\end{array}$ & $\begin{array}{l}\text { Pijj-u } \\
\text { COPL-3MS.SM }\end{array}$ & $\begin{array}{l}k a k \partial m \\
\text { as }\end{array}$ & $\begin{array}{l}\text { kuna-tat-u } \\
\text { condition-PL- } \\
3 \mathrm{MS}\end{array}$ & $\begin{array}{l}z \dot{i}-k^{\prime} k ' \hat{t} j r-o \\
\text { REL-change- } \\
\text { 3MS.OM }\end{array}$ \\
\hline
\end{tabular}

'No no... it is the nurse who can change it as condition allows.'

$$
\begin{array}{lll}
O K & \text { tixikl! } & \text { Pijj-u. } \\
\text { ok right } & \text { COPL-3MS.SM } \\
\text { 'Ok, it is right!' } &
\end{array}
$$

In the sentences (20) and (21) above, Tigrinya speakers switch the negative marker No no... instead of saying ?aj-konənə, ?aj-falun and jallən to portray disagreement, and ok to show approval instead of ? $u j$, $\hbar r a j$, and $? w \partial$.

To wind up, from these findings Tigrinya-English bilingual individuals highly prefer to mix codes intrasententially. They only switch the small-sized constituents of the language items frequently by inserting the words or phrases to the syntactic structures of Tigrinya going back and forth. This implies that the bilinguals have unbalanced language skill between the matrix and embedded languages. Therefore, this finding is appropriate to the findings of different studies. For example, according to Studies of child bilingual language acquisition (McClure1981; Zentella 1981) and adult bilingualism (Poplack 1979) as cited in Seligson (1986, 313) frequent intrasentential code-switching is associated with high bilingual ability, whereas use of intersentential switching is associated with non-fluency or dominance in one language over the other.

The Tigrean trilinguals are not only mixing the small-sized linguistic constituents, but they are involving multiple constituents and constituents from different languages (Amharic and English) within a sentence or clause at the same time. They are constructing such mixed Tigrinya which is grammatically well-formed in the ML. They do not commit errors in code-switching while engaging in code-switching phenomenon intrasententially. Therefore, Tigrean trilinguals have high proficiency of the embedded languages (English). According to (Becker 1997), as cited in Bishop $(2006,11)$ confirmed this reality as:

An individual's level of second language ability can be demonstrated through his manner of codeswitching. For example, those with low levels of proficiency (such as those at the early stages of second language acquisition) engage in intersentential switching.

As has been described so far, embedded language constituents were small-sized which switched intrasententially. Thus were, intrasentential code-switching is very risky. Here, codeswitchers may mix code flexibly going back and forth unlike intersentential types of codeswitching. Auer and Muhamedova $(2005,35)$ elaborate the grammaticality of intrasentential code-switching as:

There is, then, a strict division of the realms of the two grammars: ideally, the grammar of the matrix language provides the grammatical frame of the sentence/clause as a whole, while the grammar of the embedded language is used in complex insertions.

\section{Conclusion}

As can be cognized from the findings, this study provides some information about switched language items on the FM radio Tigrinya programs. It also portrays an insight for researchers of sociolinguistic who are interested in studying codeswitching on Medias in general and radio services in particular.

The structural perspective of codeswitching is dealing with the linguistic description and analysis of Tigrinya-English codeswitching on the Tigrinya radio FM programs. It is also possible to conclude, 
intrasentential type of codeswitching is appropriate in Tigrinya-English code-switching. Thus, this finding is similar to Seligson (1986) and Zelealem (1998) in this case English words are switched in free morpheme form into the Tigrinya language. Therefore, English verbs are switched into the Tigrinya morpho-syntactic realms

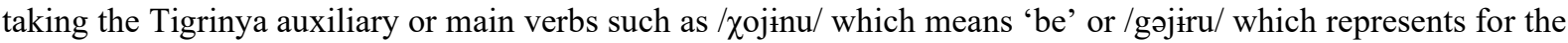
equivalent English word 'do'.

\section{Recommendation}

As could be recognized from the findings of this study, code-switching born predicaments are explored or characterized. Here are some suggested actions which should be undertaken to resolve these problems.

$>$ Newscasters should try to transmit clearly and precisely designed language (Tigrinya used on the media) without mixing other languages, and they must contribute their professional skill to upscale Tigrinya standardization, to assuring language 'purity'.

$>$ Interviewees should be aware not to speak switched Tigrinya (Tiglish) for there are monolingual listeners from each corner of the city. They should be informed before commencing the live discussion programs by the journalists.

$>$ Concerned bodies and educators should take the responsibility to mobilize individuals to carry out research on how to standardize Tigrinya language, lexicalize and develop independent Tigrinya from any indigenous or foreign languages influences situationaly.

$>$ Language editors should look seriously for the switched Tigrinya especially for the words, phrases or clauses which haphazardly written with switched language items but have their equivalent meaning in Tigrinya.

$>$ Regional Language Academy should be established in order to enhance the use of the language and to carry out the research for betterment of the language.

\section{Reference}

Auer, Peter and Muhamedova, R. 2005. 'Embedded Language' and 'Matrix Language.' In insertional Language Mixing: Some Problematic Cases." Rivista Di Linguistica 17(1):3554http://linguistica.sns.it/RdL/17.1/03.Auer_01.De_.pdf.

Berk-Seligson, S. 1986. "Linguistic Constraints on Intrasentential Code-Switching: A Study of Spanish/Hebrew Bilingualism." Language in Society15 (3):313-348.

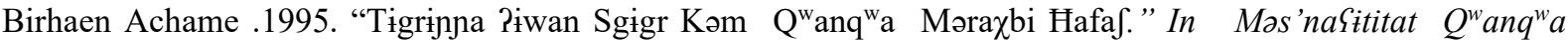
Tigrinna, eds. T/Haimanot et al., 610-642 .Addiss Ababa: Birhanina Səlam.

Bishop, M.Maier.2006. The Role of Language Codeswitching in Increasing Advertising Effectiveness among Mexican-American Youth. Arlington: The University of Texas. http://gradworks.umi.com/32/42/3242659.html.

Gass, Kate.V. n.d. Grammatical Constraints on IntrasententialCodeswitching:EvidencefromEnglishAfrikaansCodeswitching.http://sun025.sun.ac.za/portal/ page/portal/Arts/Departments/linguistics/documents/SPILPLUS31VanGass_article.pdf

Mekonnen Birhane .1995. "Tigrinya: Genesis and Development." In Mas'naৎtitat $Q^{w} a n q w a$ Tigrinna, eds.T/haimanot et al, 56-74 .Addiss Ababa: Birhanina Səlam.

Pfaff, C.W. 1979. "Constraints on Language Mixing: Intrasentential Code-Switching and Borrowing in Spanish/English.” Language 55(2):291-318.

Romaine, Susan.1995.Bilingualism .Oxford: Black well.

Widdowson, H.G., ed.1998. Sociolinguistics. London: Oxford University Press.

Zelalem Leyew. 1998. "Code Switching: Amharic and English.” Journal of African Cultural Studies11 (2):197216.doi: 101080/13696819808717834. 